\title{
The portrait of gender justice and injustice in the Islamic teaching text- book and Muhammadiyah teachers' responses
}

\author{
Nurwanto \\ Universitas Muhammad iyah Yogyakarta \\ nur_lippro@yahoo.com
}

\begin{abstract}
The paper investigates the textbook on Islamic teaching officially published for Muhammadiyah Senior Secondary Schools. It examines whether the textbook promotes gender justice or injustice. In addition, how the teachers think about the gender discourse is also explored. The study seems important to carry out by taking account of whether the trend of gender discourses which has taken place for some decades in the public is substantially accommodated in the Muhammadiyah schools' curriculum. Moreover, the teachers' responses to the existing gender issues as included in the textbook may be crucial to shape since they are translators of the text offered. To clarify this issue, the paper uses content analysis of the textbook and analyses the result of interview with several Muhammadiyah senior secondary schools' teachers in Yogyakarta. The result of this study shows that even if the content of the official textbook generally emphasizes gender justice, in some cases, it promotes gender injustice and stereotypes. The explanation of men's social roles in the whole Muslims' history tends to be widely explored whereas that of the possibility of women's roles is paid less attention. On the other hand, in other parts of the textbook, there is an explanation of the
\end{abstract}


importance of democratic attitudes for Muslims in the framework of societal relations. In the sense, the elaboration of the possibility of men and women to participate in the public is theologically explained. With regard to the teachers' responses, the writing indicates that they generally agree with the notion of the need for women and men to share and possibly contribute in the public as long as the women in particular do not deny their domestic roles. They seem trying to examine the content of the textbook ranging from rational up to theological considerations. To conclude, the textbook contains gender justice and injustice orientations which have been responded variously by the teachers.

Kajian ini menelaah buku teks tentang ajaran Islam yang resmi diterbitkan untuk Sekolah Menengah Atas Muhammadiyah. Kajian ini menguji apakah buku teks tersebut mempromosikan keadilan atau ketidakadilan gender. Di samping itu, kajian ini mengeksplorasi bagaimana para guru berpikir mengenai wacana gender. Kajian ini penting untuk mempertimbangkan apakah kecenderungan wacana gender yang telah terjadi beberapa dekade ini secara substantif diakomodasi oleh kurikulum sekolah-sekolah Muhammadiyah. Lebih jauh, respon para guru terhadap persoalan-persoalan gender yang ada sebagaimana termuat dalam buku teks menjadi penting karena mereka merupaka para penerjemah dari buku teks tersebut. Untuk mencapai itu semua, kajian ini menggunakan analisis isi atas buku teks dan menelaah hasil wawancara dengan beberapa guru Sekolah Menengah Atas Muhammadiyah di Yogyakarta. Hasil kajian ini menunjukkan bahwa meskipun secara umum muatan buku teks resmi menekankan keadilan gender, dalam beberapa hal, juga mempromosikan ketidakadilan gender dan prasangka. Penjelasan mengenai peran sosial lelaki dalam keseluruhan sejarah Muslim cenderung memperoleh paparan luas, sementara peran sosial perempuan kurang memperoleh perhatian. Di sisi lain, sebagian buku teks juga menjelaskan tentang pentingnya sikap demokratis bagi Muslim dalam kerangka hubungan-hubungan sosial. Dalam hal ini, elaborasi mengenai peluang lelaki dan perempuan untuk berpartisipasi dalam ruang publik telah dijelaskan secara teologis. Dengan memperhatikan respon paraguru, kajian ini menunjukkan bahwa mereka umumnya sepakat dengan paham mengenai erlunya perempuan dan lelaki berbagi dan mungkin berkontribusi dalam ruang publik sejauh perempuan tidak menolak peran domestik mereka. Mereka agaknya mencoba menguji muatan buku teks melalui pertimbangan rasional hingga teologis. Akhrinya, buku teks bermuatan 
orientasi keadilan ketidakadilan gender yang telah direspon secara berbeda oleh para guru.

Keywords: Gender; Justice; Injustice; Muhammadiyah; Teachers'
Responses

\section{Background}

One of the most significant current discussions in public discourses is a physical difference between men and women which has often been seen as justification to endorse an injust culture amongst them. The societal view and interpretation towards such a sexual difference is called gender. ${ }^{1}$ The gender injustice which can simply be defined as inequal social treatments between men and women ${ }^{2}$, generally takes place in society, for example the ignorance of females' roles in public. ${ }^{3}$ In addition, there are likely that the educational access to females is lower than that to males especially in the third world, ${ }^{4}$ the division of work between husband and wife tends to be imbalanced in their family and even gender bias of knowledge in school is transformed through textbooks. ${ }^{5}$ Such facts of gender injustice, of course, have longer been contested and shaped if supported by social behaviours and educational processes including textbooks (part of curriculum) which legitimize the social injustice forms. ${ }^{6}$ For this reason, the issue of gen1.

${ }^{1}$ Nasaruddin Umar, Argumen Kesetaraan Gender dalam Al-Quran. Jakarta: Paramadina, 2001,

'UNIFEM, Gender Justice: Key Achieving the Millennium Development Goals, 2010, 3.

3Fahriani, "Mewujudkan Demokratisasi di Ruang Publik", 2005 in http://www.indopos.co.id, accessed in March 2008.

${ }^{4}$ MavinC. Alkin (ed.). Encyclopedia of Educational Research Sixth Edition. New York: Macmillan Publishing Company, 1992, 1525,

${ }^{5}$ Acmad Muthali'in, Bias Gender dalam Pendidikan. Surakarta: Muhammadiyah University Press, 2003, 215-223.

${ }^{6} \mathrm{~N}$. Durrani, "Schooling the 'Other': Representation of Gender and National Identities in Pakistani Curriculum Text. Compare, volume 38, no. 5 (2008): 595-610. 
der injustice not only correlates with that of schools' access but also a possibility of the content of curricula being taught.

In the context of education, Mulia said that the spreading of values containing gender biases can be looked at a number of texbooks. The portrait of females in the textbook of Indonesian language, social sciences, physical science and art in elementary schools seems to have generally been placed in domestic roles, on the other hand, males are merely oriented to public and 'productive' activities. In detail, the substance of such texbooks draw to attention to the fixing of the males and females' social roles. For instance, 'a wife usually stays at home while her husband works at his office'; 'a husband enjoys his food and drink first and his wife afterwards'.7 By describing so, it may be clear that, socio-culturally speaking, the male is in a dominant image rather than the female.

In terms of theological understanding, the imaging of the male and female seems injustly supported also by religious texts. The interpretation nuance is by means partly due to different social settings where an interpreter lives. Within a religious community which is socially patriarchal, the female only works at home and is prepared to serve her husband whilst the male has public activities freely and seems to be led to have been his family backbone. Even such a tendency is likely that the female is just to be a complementary, secondary element of the male and her society. This understanding is not only recognized but also convicted. Thus, as Feillard ${ }^{8}$ said, the injustice of the females' social roles is highly endorsed by the conservative who sustains an oldfashioned social practice which is not sensitive to social injustice. Con-

"Siti Musdah Mulia, "Pendidikan Berwawasan Keadilan Gender", accessed through http:// www.icrp-online.org/wmview.php?ArtID=525\&page=6, on 15/3/2008.

${ }^{8}$ Andree Feillard, "Indonesia's Emerging Muslim Feminism: Women Leaders on Equality, Inheritance and Other Gender Issues", Jurnal Studia Islamika, Vol. 4, Nomor 1 (1997): 83-111. 
trasting to that circumstance, in a relatively egalitarian society, the male and female have an equal right to get involved in both the public and the domestic. Amongst Muslims, however, there is a limitation to which the female should be aware of her destiny which is usually associated with the domestic responsibility such as pregnancy and breastfeeding.

If criticized further, the content of Islamic teaching in school for instance, may still be found an injust gender interpretation even if there is a likelihood that an embryo of justly-led religious understanding can be read. Moreover, an effort of accommodating a social demand that many recent females work in the public sector-even amongst them there are the ones who can show good achievement-though it has not been a mainstream yet. Interestingly, a part of religious adherents-Muslims especially-iniatially offer a critical point of view in rereading and reflecting their understandings of the gender role. It seems that, nowadays, there have been dynamism, tensions and changes of religious interpretation of it.

So far along with my colleagues, I have studied the tendency of gender discourses in the texbook of Al-Islam published in 1996 by the the Basic and Middle Education Council (officially called: Majelis Dikdasmen) of the Central Board of Muhammadiyah applied to all Muhammadiyah Senior Secondary Schools throughout Indonesia. ${ }^{9}$ As an educational institution within a modern organization, Muhammadiyah, which has a credo: 'return to the Holy Quran and the Hadith (the Prophet sayings)', the Muhammadiyah schools are by no means to go far away from the just interpretations of gender. From my reading, in that text book edition, there was a tension in creating a relatively new

${ }_{9}^{9}$ Majelis Dikdasmen PP Muhammadiyah, Al-Islam 1IIb, Yogyakarta: Pustaka Suara Muhammadiyah, 1996. 
understanding of gender sensitivity. The different understandings of certain verses in the Holy Quran are still contested. The finding of my initial study showed that there are some analyses of the texts, either Quran or Hadith, which are read and meant carelessly. Such types of analysis are surely able to result in certain beliefs or even hesitance among students.

The evidence of gender bias in that textbook edition for example could be comprehended from the statement below: 'Males and females are the two categories of human beings which have similarities and differences. The most intriguing difference is of soft feelings and behaviours. The female in general responds to everything through such soft feelings she has'.10 The statement draws attention that the females tend to be known as those who dominantly make use of their feelings and emotions rather than the males who may-implicitly speaking-use their logic (ratio). An implication of this point of view is that the males are more likely to be educated and possible to think logically, so that they are prepared by their parents to access to formal education, than the females who are less logical, yet feelingly fascinating. The question here is that is the belonging of the trained, soft feeling the outcome of education, therefore changeable, or is it taken from granted? As long as it is concerned, the above statement tends to place the quality of feeling as something given from God. It may be similar to say that the men in general have no right to boost their soft, wise feelings.

Besides stating as above, the book also tries to provide a particular meaning of the Hadith narrated by Ahmad and Abu Daud, mentioning that 'indeed a female is part of a male'. The meaning given in this book is that 'the Hadith asserts that the female is actually complementary to

10Majelis Dikdasmen PP Muhammadiyah, Al-Islam 1IIb..., 41. 
the male in many cases. In the sense, the female either gets relatively the same task as the male, or has the similar right as the male's own. As a matter of facts, there are considerable social, political and economic activities which can be accomplished by the female ${ }^{\prime 11}$. By looking at the message of that statement, it may be important to say that the phrase 'relatively the same task' and 'the similar right' can shape double meanings. Yet, it may be said that these phrases accentuate on the carefullness of placing the gender interpretation on a Muslims' point of view. A further meaning of the statement reveals that the women may be able to participate outside their home ('the similar right') as long as they are not to go beyond God's determination (thus it is not absolutely the same as the men). It seems that such a meaning of the textbook has offered 'a more moderate perspective'-though it has not been yet clear and in-depth-than the old perpective by which women are generally limited or even banned to work in the public.

By taking account of my finding of a few of the textbook content (1996 edition), along with my students (in joint research), I reviewed again the textbook in the new edition, 2008. As I see it, there are many changes especially in forms of lay out, images put to ilustrate the content and the revision of interpretation of texts related to gender issues. The questions is whether the new edition of the textbook has become more genderedly sensitive or not. In the new edition, there are some pictures intended to draw attention to the roles of men and women in certain activities. Even if, such pictures linked to a great deal more explanation of gendered issues may be regarded as simple or even simplified, the work of Muthali'in ${ }^{12}$ is worth mentioning that gender

${ }^{11}$ Majelis Dikdasmen PP Muhammadiyah, Al-Islam 1IIb..., 42.

${ }^{12}$ Achmad Muthali'in, Bias Gender dalam Pendidikan, Surakarta: Muhammadiyah University Press, 2003. 
injustice in some elementary schools' textbooks used in Surakarta was also because of photoes, images and ilustrations given. In the sense, the study also partly investigates this kind of evidence.

What has been noted above can be at least the reason why the study on the revised textbook of Al-Islam published by the Basic and Middle Education Council correlated with the issue of gender justice and injustice needs to be carried out. Along with strengthening the gender mainstreaming, Muhammadiyah schools' curricula may also need to pay attention to the interpretation of Quranic verses and Hadith contents teaching about men and women's social roles. To what extent does the Council offers its view of gendered issues within the revised textbook of Al-Islam? Was there any balanced arguments between the meaning of gender justice and injustice? Is there anything unique offered by Muhammadiyah schools' curricula regarding gender issues? Such questions will be a focus explored in this study. In order for this study to be more clarified, some teachers of Al-Islam as the users of the textbook would be interviewed on how they respond to the gendered issues within it, whether they sound the same as written and meant in the text or they have different understandings as taught to their students.

This paper has been divided into three parts. The first part deals with the literature review of mainly gender justice and injustice. The next is in line with the findings consisting of textual statements of the textbook implicitly or explicitly assumed to shape gender justice and injustice. The last describes what the teachers of this subject say about the gendered religious issues written in the textbook. Thus, it can be said that the writing portrays what is textualized in the textbook and what is thought about by the teachers. 


\section{Research method}

The writing is based on qualitative research which consists of noninteractive and interactive stages. ${ }^{13}$ The former emphasizes library research namely the textbook of Al-Islam published by the Basic and Middle Education Council of the Central Board of Muhammadiyah in 2008 (revised edition). ${ }^{14}$ Analytically discussed in this writing is only the book of Muhammadiyah's senior secondary schools for class $X$ (the second semester). The latter, an interactive stage, leads to clarify the issues of gender justice and injustice offered in the textbook with its teachers' responses. The teachers interviewed are basically the ones who teach this subject in the Muhammadiyah's senior secondary schools located in Yogyakarta. In terms of data analysis, the content analysis is generally chosen to look into the details of textual statements and meanings provided in the textbook. Furthermore, what the teachers responded to the content is also substantially analysed. Thus, it can be said that what is written in the textbook and what is said (thought) by the teachers are tried to be discussed so as to find a conclusion and then probably practical recommendation to improve the textbook content to be more sensitive of gender.

\section{Findings and discussion}

\section{The general map of the textbook content}

The content of the textbook of Al-Islam for Class $\mathrm{X}$ consists of such studies as the Quran and Hadith, Belief, Ethics, Islamic Jurisprudence, Tarikh and Kemuhammadiyahan. The instances of the topics offered in the study of the Quran and Hadith, for instance, are democracy

\footnotetext{
${ }^{13}$ Nina Sukmadinata, Metode Penelitian Pendidikan, Bandung: Rosda, 2005, 61.

${ }^{14}$ Majelis Dikdasmen PP Muhammadiyah, Al-Islam Xb Yogyakarta: Pustaka Suara Muhammadiyah, 2008.
} 
from Quranic perspectives, religiosity and sociality, and the human existence on the earth. As fas as it is concerned, details of the above topics such as 'democracy' accentuate that there is an extention of the study of Al-Islam by accommodating such modern discourse as democracy. However, from the challenging tendency of the study, the discourse of gender seems still absent to textually portray in this subject. Therefore, the discourse of gender from the textbook is rather taken from implicit understandings.

\section{Gender injustice}

There are a couple of pictures put on to illustrate or add an explanation of certain issues. For instance, there is a picture which describes a man who is doing a prayer whilst another picture shows a woman who is primping (see Picture 1 dan 2). ${ }^{15}$ If analysed, the former picture may be neutral but, in terms of the balance of information, it is slightly bias. Here there is no further explanation to assert that all human beings, either men or women, have the same right as slaves and worshippers of God. ${ }^{16}$ This imaging may affect to a stereotype that men are seen as those who are religiously loyal rather than women. It can emerge because of the lack of sufficient explanation about such a picture. The same case may also be linked to the second picture. Explicitly, the book gives details that 'primping or dressing up is part of humans' needs', which is naturally desired by men and women, however, the image exposed is that of only a woman. In the sense, there is no relevance between the picture and the given explanation. Thus, even if those pictures are just to enrich the content, their function may impact on certain values, especially those of gender insensivity.

\footnotetext{
${ }^{15}$ Majelis Dikdasmen PP Muhammadiyah, Al-Islam Xb..., 38.

${ }^{16}$ Nasarudin Umar, Argumen Kesetaraan Gender..., 248.
} 

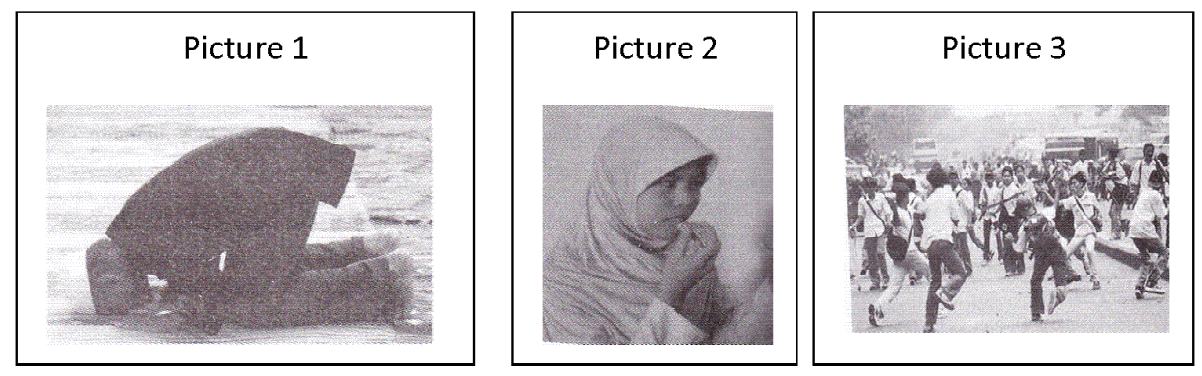

Another picture is a number of male students who altogether are committed to perpetuate violence, brutally fighting against each other (see Picture 3$).{ }^{17}$ In a social reality, violent actions may very often be conducted by a group of men, but in some cases-as nowadays depicted by television station-a couple of women also commit perpetuating violences for instance the fenomenon of a gang named 'Nero' in Bandung, the West Java. It seems that such a picture could result in the impression that a man or a group of men generally have a bad or temperamental attitude. However, the assertion of such a stereotype would also mean that women who may have opposite attitudes which tend to be soft and gentle, could no longer be clarified. As long as it is concerned, the explanation of Picture 3 may be applicable for example if related to the Chapter of Ali-Imran: 159 as included in another chapter of the textbook ${ }^{18}$ which makes clear that 'it is by God's grace that you deal gently with them. Had you been harsh and hard-hearted, they would surely have broken away from you'19 This verse generally explains that the Prophet Muhammad as a man was known and suggested to behave softly and not to perpetuate violence in encountering any situation and challenge. In the framework of humanity at large,

\footnotetext{
${ }^{17}$ Nasarudin Umar, Argumen Kesetaraan Gender..., 47.

${ }^{18}$ Nasarudin Umar, Argumen Kesetaraan Gender..., 2.

${ }^{19}$ see the verse translated by Sayyid Qutb, In the Shade of the Qur'an..., 217.
} 
Islam actually endorses to cultivate a figure whose attitude is individually and socially pious, for both men and women. With regard to the picture provided, therefore, the textbook needs to give related and wide explanations sufficiently so as to reduce the possible gender biases.

When explaining the ethics of relationship between males and females, the textbook specifically quotes a Hadith narrated by Ahmad as follows: 'Be careful as you are in a meeting with a woman. In the name of Allah and my soul in His hand, there is no man with a woman, except an evil will be between them'.20 There are two important aspects which need to be analysed from this Hadith, namely: its validity and substance. Related to the former, this writing does not pretend to investigate it, but the latter, instead, may be important to examine briefly. The textbook does not clearly explain why the woman who tends to influence the man. Due to the absence of explanation, it could sustain the stereotype of women as the source or origin of badnesses whilst men may become victims of what women act. In short, an aspect which may disappear from this book is the more scientific explanation of the content of Hadith which contains gender bias and, consequently, it may be able to produce controversy in terms of gender sensitivity.

In the study of Islamic history (Arabic: Tarikh) about four Islamic leaders after the Prophet (Arabic: Khulafaur Rasyidin), the offsprings of Umayyah and those of Abbasyiyah, ${ }^{21}$ the textbook incorporates such names as Abu Bakar, Umar ibn Khattab, Usman ibn Affan and Ali ibn Thalib, but, unfortunately, female figures such as Khadijah and Aisyah are not mentioned. In addition, some politicians and scientists stated in the text are all men. For this reason, why were not women who had involved in the spreading of Islam, the making of Muslims'

\footnotetext{
20Majelis Dikdasmen PP Muhammadiyah, Al-Islam Xb..., 46.

${ }^{21}$ Majelis Dikdasmen PP Muhammadiyah, Al-Islam Xb..., 89-98.
} 
civilization and other public roles, written in the textbook? The content of the book is likely to shape that as though the dynamics of Islamic struggle only belong to men. The tendency to place a big part-not to say 'all the things'-of Muslims' history in the hand of men seems to have been an issue taking place in many aspects of humans' history from many group of people, either religion or nation. Referring to Umar's opinion, ${ }^{22}$ such a patriarchal social stance, emphasizing that men have more authority over women, is by means a cultural construction. Thus, such a historical analysis can be 'homework' for those concerned with Muslims' history codification to re-write it so as to be balanced and fair in terms of the possibility of men and women social contributions.

What is previously shown reveals that the textbook tends to construct some stereotypes of men as the ones whose spirituality are more enhanced and whose characters are more temperamental than women. In contrast, women are stereotyped as the ones who have more softness and, unfortunately, are subordinate of men. Further, as illustrated in picture 3 , men are connotated with violence perpetuation whilst at the same time women are constructed as the culprits of any badness by quoting a Hadith narrated by Ahmad without any criticism. In the sense, the textbook needs to make clarity to every viewpoint which can produce gender injustice in terms of stereotyping tendency (look at Hermawan's work in Table 1). This finding seems the same as the work of Muthali'in ${ }^{23}$ and Durrani ${ }^{24}$ which draws attention to some textbooks available in schools trapped in unfair gender stereotyping. Additionally, quoting and explaining some related verses in the Holy Quran and Hadith appropriately are pivotal so as to analyse the contents with

\footnotetext{
${ }^{22}$ Nasarudin Umar, Argumen Kesetaraan Gender..., 130.

${ }^{23}$ Achmad Muthali'in, Bias Gender dalam Pendidikan..., 2001.

${ }^{24} \mathrm{~N}$. Durrani, "Schooling the 'Other': Representation of Gender and National Identities in Pakistani Curriculum Text", Compare, vol. 38, no. 5 (2008): 595-610.
} 
gender sensitivity more accurately as well. Thus, by so doing, the injust gender construction through the textbook can be reduced.

\section{Genderjustice}

As well as finding the content of the textbook examined as shaping gender injustice, the writing also identifies some statements and images which can be included as the portrayal of gender justice. The textbook explains that,

'At the first time, along with his wife, Adam was instructed by God to live in the heaven ${ }^{25}$, a devil then attempted to persuade them to break what God had banned: they ate the banned fruit. The devil's ruse towards Adam and his wife finally succeeded. Consequently, they were sent down to the earth. (To deal with this condition), they asked for forgiveness from God'.26

The above story which contains how Adam and Eva had been sent down to the earth is likely to be in line with the principle of gender equality. Both figures are regarded as those who are potentially able to do sins and they have had the same position before God in receiving forgiveness. Such a theological understanding seems pivotal to deliver with regard to the humanistic Islamic world view.

Another point of view shown in this book is that 'inhabitants living in this planet, the earth, consist of men and women with different races, either white, black or brown ... (are from) many nations and ethnicities.'. ${ }^{27}$ In addition, 'the task of human beings is to become a vicegerent on the earth. It is a special task given by Allah to every people'.28 From both statements, it can be said that, irrespective of various social backgrounds and races, humans have had equality to be leaders and

\footnotetext{
${ }^{25}$ Majelis Dikdasmen PP Muhammadiyah, Al-Islam Xb...,18.

${ }^{26}$ Majelis Dikdasmen PP Muhammadiyah, Al-Islam Xb...,19.

${ }^{27}$ Majelis Dikdasmen PP Muhammadiyah, Al-Islam Xb...,12.

28Majelis Dikdasmen PP Muhammadiyah, Al-Islam Xb...,15.
} 
sustainers of the world, who are capable of making use of this world for better humanity and life. The illustration in this book, however, would possibly be more various and in-depth if compared from other various viewpoints regarding the existence of the first human being on the earth.

More importantly, the book also asserts that, in terms of public participation, men and women have an equal role as cited that 'Islam regards human beings as equal and does not grant a privilege to certain groups of people ....29 Further, it also axplains that 'in a meeting, there is an activity which mirrors the right and obligation equality and the same treatment among participants. ${ }^{30}$ However, it seems that the content of the text uses a general expression 'the same treatment among the meeting's participants' instead of providing a specific phrase such as 'either a man or a woman'. The meaning of the latter case may refer to the notion that women who possibly get involved in the meeting by means have a right to vote and the same chance as men have in making a decision. However, the assertion of the term 'men' and 'women' is not textually mentioned in the text. As long as it is concerned, to draw attention to both terms is important as culturally, the domination of men in any decision making tends to be constructed and socially sustained.

The principle of equality before God's law is also written in the text as stated that 'alms giving must be fulfilled by every Muslim in the end of the Ramadan month, either the young or the old, men or women .....31 Besides, there is a Hadith quoted, for example, that the Messenger has made the alms giving in the month of Ramadan compulsory as many as two a half kilograms of date palms or wheat flour to every Muslim who is,

\footnotetext{
${ }^{29}$ Majelis Dikdasmen PP Muhammadiyah, Al-Islam Xb...,1.

30Majelis Dikdasmen PP Muhammadiyah, Al-Islam Xb...,1.

${ }^{31}$ Majelis Dikdasmen PP Muhammadiyah, Al-Islam Xb..., 52.
} 
either free or slaved, either a man or a woman'.32 This Hadith narrated by Bukhari and Muslim (see the book of Bulughul Maram) reveals that the assertion of the Prophet on the responsibility of men and women in completing this religious obligation is able to be a signal of the absence of gender bias in the application of this law. Additionally, the same responsibility between them is also stated in the following Hadith: 'He (Muhammad) had said that if Fatimah (his daughter) stole, I would cut her hand'.33 The text, thus, asserts that the Prophet taught us to be just even if it affected to his daughter. In a nutshell, the text highly endorses law justice to any people, men or women.

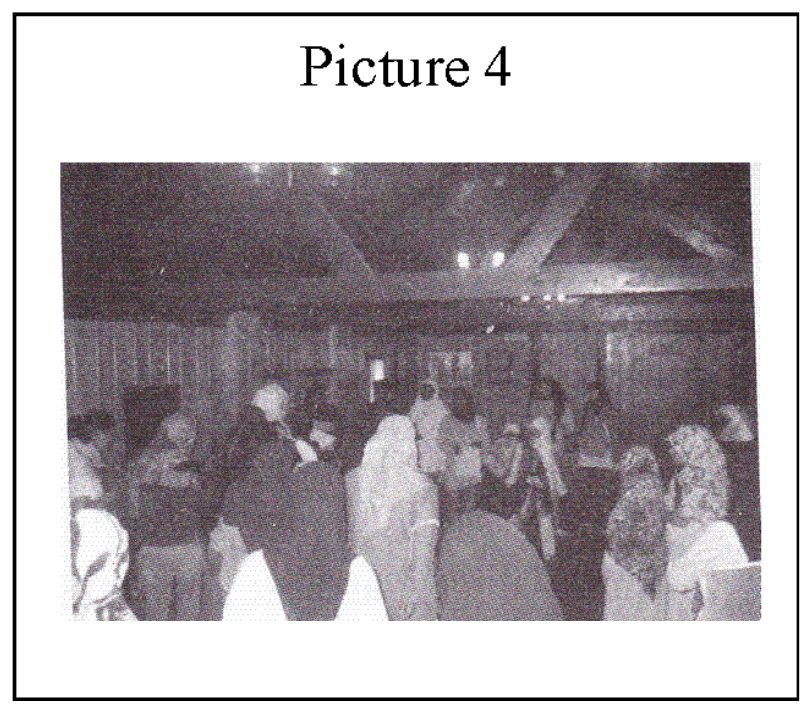

An attention drawn to women's participation in the public seems to be clearly described in the text. Picture 4 for instance, may represent the endorsement of women's religious participation. The picture shows that women have the same opportunity to be intellectually and socially

32Majelis Dikdasmen PP Muhammadiyah, Al-Islam Xb..., 53.

${ }^{33}$ Majelis Dikdasmen PP Muhammadiyah, Al-Islam Xb..., 87. 
enhanced. ${ }^{34}$ Another image, in addition, illustrates a chance for men and women altogether to conduct pilgrimage in the Holy land, Mecca. ${ }^{35}$ The same possibility between men and women to reach God's blessings through such worship is accentuated. Furthermore, as a religion bringing the idea of justice, Islam has boosted the freedom and progressiveness of women. The book cites that they (therein Aqabah pledge) also promised to advocate their Prophet as they supported their wives and children'. ${ }^{36}$ The latter declaration emerged due to the difficult circumstance where women had generally been domesticated, in particular before the emergence of Islam brought by the Prophet Muhammad (pbuh). It may be clear that these texts range from the universal advocacy to all humans, both males and females, until the particular advocacy to women who are socially marginalized in certain periods of time.

One of the verses often cited in any discourse of Islamic egalitarianism is that of the Chapter of Al-Hujurat: 13. The verse states that ' $O$ mankind! We created you from a single (pair) of a male and a female, and made you into nations and tribes, that you may know each other $\ldots{ }^{137}$. The citation to this verse may generally be appropriate but, unfortunately, the issue of gender is not clarified or explained better by providing such real cases as social injustice including social treatments to men and women. Next, the citation of the Chapter of At-Taubah verse 71 which mentions that 'the believers, men and women, are protectors of each other: they enjoin what is just and forbid what is evil', ${ }^{\prime 8}$ is also only a Quranic text written in the book without any explana-

\footnotetext{
${ }^{34}$ Majelis Dikdasmen PP Muhammadiyah, Al-Islam Xb..., 43.

35Majelis Dikdasmen PP Muhammadiyah, Al-Islam Xb..., 49.

36Majelis Dikdasmen PP Muhammadiyah, Al-Islam Xb..., 82.

${ }^{37}$ Majelis Dikdasmen PP Muhammadiyah, Al-Islam Xb..., 12.

38Majelis Dikdasmen PP Muhammadiyah, Al-Islam Xb..., 105.
} 
tion. Even if the verses as such are included, however, the doctrinaire approach typifies the content of the text. Therefore, practical considerations will be likely to be an important key to enrich the textbook.

As well as showing that there are gender biases in the textbook as previously mentioned, another finding reveals that there is also gender fairness in shaping men and women's roles. Its content actually refers to some Quranic verses and the Prophet sayings which shape the balanced roles between men and women. By taking account of Tilaar's work, ${ }^{39}$ the image of men and women here is placed in the stand for completing each other in this life. Besides, the emphasis of the same position between them before God's law can make their optimism into being, either socially or spiritually to reach the best from their Lord. The appropriate choice of related Quranic verses to explain the place of men and women in the universe possibly becomes the excellence of this book, but it would be challenging if not clarified by providing practical and comprehensive considerations. Because, if the latter, the merely doctrinaire approach takes place, the content of the subject can possibly ignore the potentiality of the emergence of gender injustice and other un-fair social understanding construction.

\section{Teachers'responses}

To examine the extent to which the content of the textbook is perhaps responded by the teachers of the subject, some of them working at Muhammadiyah schools in Yogyakarta had been interviewed. The area interviewed is related to the general issue accommodated in the textbook and some detailed explanation of both gender justice and injustice found out in this writing.

${ }^{39}$ H.A.R. Tilaar, Perubahan Sosial dan Pendidikan: Pengantar Pedagogik Transformatif untuk Indonesia, Jakarta: Grasindo 2002. 
Regarding the general issues of the textbook, a teacher said that 'the content of Al-Islam officially called ISMUBA in Muhammadiyah's schools is to educate students to be pious generations'. ${ }^{40}$ To accentuate on practical benefits, another teacher said that 'what is needed in Muhammadiyah's schools is not merely a cognitive, remembered aspects of materials taught, but what directly affects to their daily life'.41 These general responses are commensurate with an orientation of the existing national educational standards issued by the Government ${ }^{42}$ which promotes Religious Education (RE) in line with the goal to manifest individually and socially pious generations in society. In the sense, Al-Islam being taught in Muhammadiyah's schools would have a challenge of dealing with an issue of how to internalize Islamic values, rather than merely how to transfer Islamic knowledge.

Relating to the intended curriculum to internalize Islamic values, the teaching of gender justice is one of the recent important topics needed to be discussed. According to Mukhlis ${ }^{43}$, the discourse of democracy offered in the textbook may become a general topic which includes details of studies such as gender equality. However, he asserted that such an issue must be filtered with an insight as stated in the Holy Quran and Hadith. Here, he examined that Islam provides a great deal more about the possibility of female Muslims to articulate their votes and actualize their potentials provided in line with the Islamic ethics such as their main task of taking care of their children. He adds that it may be true that a female can choose to what she wants as the manifestation of democracy but, for instance, she is also physically limited by nature. Moreover, Purwanto ${ }^{44}$ also argues that, in practice,

\footnotetext{
${ }^{40}$ Interview with Purwanto, 5/8/12.

${ }^{41}$ Interview with Mukhlis, 7/8/12.

${ }^{42}$ see The Regulation of National Education Minister Number 24 Year 2006.

${ }^{43}$ Interview with Mukhlis, $7 / 8 / 12$.

${ }^{44}$ Interview with Purwanto, 5/8/12.
} 
the understanding of democracy amongst students is certainly simple. For instance, how they are accostumed to speak about what they think without any hesitance, and how to try to listen to what others say about. To him, the tradition of expressing an opinion is something important to be educated based on the Quran and the Hadith. Thus, it may be clear that those teachers feel that the discourse of democracy including gender justice can be possible to deliver as long as it is reclarified with Islamic doctrines, norms and traditions.

In line with the tendency of gender justice viewpoints as illustrated and written in the textbook, some of teachers said that pictures included may not be used to completely describe Islamic messages. A teacher said that 'they are just pictures certainly dependent upon those who interprete them'. ${ }^{45}$ Such a response is right in terms of the possible lack of explanation given in the textbook, but, as previously analysed, those pictures also contain certain messages of men or women's roles hidden behind the texts. An awareness of the hidden aspect of the written statements amongst teachers is essential. In the recent discourse, teachers need to pay attention to stated as well as hidden curriculum. ${ }^{46}$ In this respect, the hidden curriculum of some pictures in the textbook can be read only if the teacher tries to understand the possible implications of certain statements or images stated. Therefore, the professional competency of the teacher of Al-Islam could not correlate with what she or he teaches as textually stated in textbook but also criticizes the possible impacts of the text in building on students' attitudes and characters. The pictures put on this writing may be obvious that they can lead students to have negative impressions towards a man or a woman as stereotyped.

${ }^{45}$ Interview with Wijayanto, 7/8/12.

${ }^{46}$ see Eric Margolis (ed.), The Hidden Curriculum in Higher Education, New York: Routledge, 2001. 
Whilst responding to the essence of gender justice as stated in the textbook, a teacher quoted a Hadith of the significance of seeking knowledge. He said that the Prophet Muhammad totally instructed Muslims in general to learn. 'There is no discrimination between men and women in getting knowledge'.47 This comment seems in line with some standpoints written in the textbook. Such verse as the Chapter of Al-Hujurat: 13 also becomes a reference among the teachers interviewed to show that the Quranic standpoints are not discriminatory to a group of people. In some cases, some of them say that several verses quoted in the textbook are basically appropriate even if they also realize that the essence of the textbook needs to be clarified and explained more so as to be sensitive of gender justice. ${ }^{48}$ For this reason, some teachers may agree that the citation of Quranic verses and the Prophet sayings which is in line with the spirit of elevating men and women's capacity and roles in society is urgent to educate for Muhammadiyah's young generations.

\section{Conclusion}

Gender sensivity issues in the textbook of Al-Islam are still contested. The general difficulties shaped are in line with the images and explanations of the women and men which are, in some cases, negatively stereotyped. Through pictures, men are labelled as the ones who refer to violence and some superiorities rather than women. In contrast, women are placed as the ones who are subordinate and the source of the bad. Another image, on the other hand, women are stereotype with softness. Such images could not actually be reduced if the sufficient explanation of certain images is ignored in the text. As a matter

\footnotetext{
${ }^{47}$ Interview with Ausath, 8/8/12.

${ }^{48}$ Interview with Mukhlis, 7/8/12 and Purwanto, 5/8/12.
} 
of facts, the lack of explanation and clarification of some images included tends to emerge. Besides the tendency of gender injuctice, on the other hand, the writing also finds that of gender justice. A big part of gender justice trends is mostly based on the Quranic verses which are quoted in the textbook and the explanation given. Such a theological understanding of the women and men's roles represented leads to the notion of shaping men and women to complete each other. The assertion of their same position before Allah's law is pivotal shown in the text. Thus, it can be inferred that the textbook provides both the gender justice and injustice discourses simultaneously.

Taking account of the teachers' responses, they seem generally receive the possibility to include the gender issue into the subject of $A /$ Islam because it is arguably in line with the Islamic teaching. Despite this standpoint, however, not all those interviewees explain more details about this issue. Thus, by looking into this limitation, the paper suggests that the textbook needs to be re-written for some angles of the gender discourses. Selecting pictures, giving more explanation and clarity and strengthening readings by offering related Quranic verses and other valid Hadith (the Prophet's sayings) are instances of the ways which can be carried out to revise and even develop the content of the textbook.

\section{Bibliography}

Alkin, Marvin C. (ed.). Encyclopedia of Educational Research Sixth Edition. New York: Macmillan Publishing Company, 1992.

Durrani, N., "Schooling the 'Other': Representation of Gender and National Identities in Pakistani Curriculum Text", Compare, vol. 38, no. 5 (2008.): 595-610. 
Hermawan, Eman. Politik Isu Tunggal: Jalan Buntu Gerakan Masyarakat Sipil (The Politic of a Single Issue: a Cul de sac for Civil Society). Yogyakarta: LKiS, 2001.

Fahriani, Laili Irma. "Mewujudkan Demokratisasi di Ruang Publik" (Manifesting Demcratization in the Public Space), 2005. Accessed through http://www.indopos.co.id/index.php?act=detail_c\&id=202036, on 15/3/2008.

Feillard, Andree. "Indonesia's Emerging Muslim Feminism: Women Leaders on Equality, Inheritance and Other Gender Issues", Jurnal Studia Islamika, Vol. 4, Nomor 1 (1997): 83-111.

Freire, Paulo. Politik Pendidikan : Kebudayaan, Kekuasaan dan Pembebasan. Translated by Agung and Fuad from The Politic of Education: Culture, Power and Liberation. Yogyakarta: REaD and Pustaka Pelajar,1999.

Karim, Khalil Abdul. Hegemoni Quraisy: Agama, Budaya, Kekuasaan (Quraish Hegemony: Religion, Culture and Power). Translated by M. F. Fatawi from Quraisy min al-Qabilah ila ad-Daulah alMarkaziyyah. Yogyakarta: LKiS, 2002.

Kristeva, Julia, "Stabat Mater" in D.T. Tietjens. Feminist Social Thought. New York: Routledge, 1997.

Majelis Dikdasmen PP Muhammadiyah. Al-Islam 1IIb. Yogyakarta:

Pustaka Suara Muhammadiyah, 1996.

Majelis Dikdasmen PP Muhammadiyah. Al-Islam Xb. Yogyakarta:

Pustaka Suara Muhammadiyah, 2008.

Margolis, Eric (ed.). The Hidden Curriculum in Higher Education. New York: Routledge, 2001. 
Mulia, Siti Musdah. "Pendidikan Berwawasan Keadilan Gender" (Education with Gender Justice). Accessed through http://www.icrponline.org/wmview.php?ArtID=525\&page=6, on 15/3/2008.

Muthali'in, Achmad. Bias Gender dalam Pendidikan (Gender Bias in Education). Surakarta: Muhammadiyah University Press, 2001.

N.N. "Mengubah Paradigma Masyarakat yang Bias Gender (Changing the Paradigm of Gender Biased Society). Accessed through dari http://reinemarie.wordpress.com, on 15/3/2008.

N.N. "Hijabisasi Perempuan dalam Ruang Publik" (Covering Females in the Public Sphere). Accessed through http://nongmahmada. blogspot.com, on 15/3/2008.

Sukmadinata, Nana Syaodih. Metode Penelitian Pendidikan (Educational Research Methods). Bandung: Rosda, 2005.

Tilaar, H.A.R. Perubahan Sosial dan Pendidikan: Pengantar Pedagogik Transformatif untuk Indonesia (Social Change and Education: An Introduction to Transformative Pedagogy for Indonesia). Jakarta: Grasindo, 2002.

Tim Penyusun Kamus Pusat Bahasa. Kamus Besar Bahasa Indonesia Edisi Ketiga. (Indonesian Dictionary, the Third Edition). Jakarta: Balai Pustaka, 2002.

Tong, Rosemarie Putnam. Feminist Thought. Australia: Allen \& Unwin, 1998.

Uhlin, Anders. Oposisi Berserak: Arus Deras Demokratisasi Gelombang Ketiga di Indonesia. Translated by Rofik Suhud from Indonesia and the "Third Wave of Democratization": The Indonesian ProDemocracy Movement in a Changing World. Bandung: Mizan, 1997. 
Umar, Nasarudin. Argumen Kesetaraan Gender Perspektif Al-Qur'an (An Argument of Gender Equality from Quranic Perpective). Jakarta: Paramadina. Bandung: Mizan, 2001.

UNIFEM. 2010. Gender Justice: Key Achieving the Millennium Development Goals.

Woodward, Mark R. (ed.). Jalan Baru Islam: Memetakan Paradigma Mutakhir Islam Indonesia. Translated by Ihsan Ali Fauzi from Toward A New Paradigm: Recent Developments in Indonesian Islamic Thought. Bandung: Mizan, 1998.

Zakariyya, Ibrahim. Psikologi Wanita (Psychology of Female). Translated by G. Saloom from Sikulujiyyah al-Mar'ah. Bandung: Pustaka Hidayah, 2002.

Interviewees

Mukhlis (Teacher at Muhammadiyah Senior Secondary School 2 of Yogyakarta)

Wijayanto (Teacher at Muhammadiyah Senior Secondary School 2 of Yogyakarta)

Ausath (Teacher at Muhammadiyah Senior Secondary School 7 of Yogyakarta)

Purwanto (Teacher at Madrasah Muallimin Muhammadiyah (Aliyah Level)) 